\title{
PENGETAHUAN PEMILIHAN SIKAT GIGI TERHADAP NILAI KEBERSIHAN GIGI DAN MULUT PADA SISWA-SISWI KELAS II C SMP NEGERI 31 JL. JAMIN GINTING KM 13,5 MEDAN
}

\author{
Ngena Ria \\ Jurusan Keperawatan Gigi Poltekkes Kemenkes Medan
}

\begin{abstract}
Abstrak
Sikat gigi merupakan alat untuk membersihkan gigi dan memijat gusi, menyikat gigi dapat menjaga kebersihan gigi dan mulut serta menghindari terbentuknya lubang gigi, kalkulus serta penyakit gigi dan gusi. Jenis penelitian yang digunakan adalah penelitian deskriptif dengan metode survey yang bertujuan untuk mengetahui gambaran pengetahuan tentang pemilihan sikat gigi terhadap nilai OHI-Spada siswa-siswi kelas II C SMP Negeri 31 Jl. Jamin Ginting Km 13,5 Medan Tahun 2018.Data diperoleh secara langsung melalui kuesioner yang diberikan sampel dan diolah secara manual. Sampel penelitian adalah total populasi 35 orang. Berdasarkan hasil penelitian, diperoleh pengetahuansiswa-siswiSMP Negeri 31 tentang pemilihan sikat gigi dengan kriteria baik 35 orang (100\%) dan tidak ada yang mendapat kriteria sedang dan buruk. Nilai $\mathrm{OHI}$-S rata-rata dari seluruh siswa-siswi (35 orang) adalah 2,32 dengan kriteria sedang. Hasil penelitian dapat disimpulkan bahwa siswa-siswi yang memiliki pengetahuan dengan kriteria baik sebanyak 100\% (35 orang) dan Nilai OHI-S rata-rata seluruh siswa-siswi adalah 2,32 dengan kriteria sedang. Diharapkan kepada seluruhsiswa-siswi kelas II C SMP Negeri 31 agar lebih memperhatikan cara memilih sikat gigi yang tepat serta meningkatkan kebersihan gigi dan mulutnya.
\end{abstract}

Kata kunci : Pengetahuan, Pemilihan Sikat Gigi, OHI-S

\section{Latar Belakang}

Sehat adalah sebuah investasi, asset, dan harta yang paling berharga bagi setiap individu.Menjadi sebuah penyempurna jika sehat merupakan titik awal untuk pembangunan. Tujuan di selenggarakan pembagunan kesehatan adalah meningkatkan kesadaran, kemauan, dan kemampuan hidup sehat bagi setiap orang agar terwujudnya derajat kesehatan masyarakat.

Masalah tingginya angka penyakit gigi dan mulut dipengaruhi oleh beberapa faktor, salah satu faktor tersebut adalah pengetahuan masyarakat tentang menjaga kebersihan gigi dan mulut serta pemilihan sikat gigi. Kebersihan gigi dan mulut merupakan hal yang penting untuk kesehatan secara umum. Pemeliharaan kebersihan gigi dan mulut dapat dilakukan dengan cara membiasakan anak untuk menyikat gigi dan memilih sikat gigi yang baik.

Dari Riset Kesehatan Dasar (Riskesdas) yang dikeluarkan oleh Departemen Kesehatan (Depkes) tahun 2007 menunjukkan 72,1 persen penduduk Indonesia mempunyai pengalaman gigi berlubang (karies) dan sebanyak 46,5 persen diantaranya karies aktif yang belum di rawat. Karies gigi (gigi berlubang) merupakan salah satu bukti tidak terawatnya kondisi kesehatan gigi dan mulut yang dapat terjadi akibat faktor menyikat gigi yang tidak baik dan benar.

Untuk menyikat gigi tentunya di perlukan sikat gigi.Sikat gigi merupakan alat untuk membersihkan gigi, menyikat gigi dapat menjaga kebersihan gigi dan mulut serta menghindari terbentuknya lubang gigi serta penyakit gigi dan gusi. Untuk mendapatkan hasil yang baik selain cara menyikat gigi, waktu dan frekuensi juga harus diketahui tentang pemilihan sikat gigi yang baik.

Kebersihan gigi dan mulut (Oral Hygiene) adalah suatu keadaan rongga mulut yaitu gigi dan jaringan gusi dalam keadaan yang bersih. Oral Hygiene dapat diperoleh bila rongga mulut bebas dari debris, kalkulus, plak dan bakteri plak yang merupakan faktor etiologi lokal terjadinya kerusakan gigi dan penyakit periodontal.

Berdasarkan latar belakang di atas, penulis tertarik untuk melakukan penelitian dan ingin mengetahui“'Gambaran Pengetahuan Tentang Pemilihan Sikat Gigi Terhadap Nilai Kebersihan Gigi dan Mulut Pada Siswa/siswi Kelas II C SMP Negeri 31, Jl.Jamin Ginting Km 13,5 Medan Tahun 2018”.

\section{Perumusan Masalah}

Berdasarkan latar belakang, maka yang menjadi rumusan masalah adalah bagaimana gambaran tingkat pengetahuan tentang pemilihan sikat gigi terhadap nilai kebersihan gigi dan mulut Pada siswa-siswi kelas II CSMP Negeri 31, Jl.Jamin Ginting KM 13,5 Medan Tahun 2018.

\section{Tujuan Penelitian}

Penelitian bertujuan untuk mengetahui gambaran tingkat pengetahuan siswa-siswi kelas II SMP tentang pemilihan 
sikat gigi terhadap nilai kebersihan gigi dan mulut di SMP Negeri 31, Jl.Jamin Ginting KM 13,5 Medan.

\section{Manfaat Penelitian}

1. memberikan tambahan informasi kepada siswasiswi tentang pemilihan sikat gigi.

2. menambah informasi tentang upaya menjaga kebersihan gigi dan mulut, terutama dalam pemilihan sikat gigi.

\section{Metode Penelitian}

Kerangka Konsep

Dalam penelitian, peneliti membuat kerangka konsep sebagai berikut :

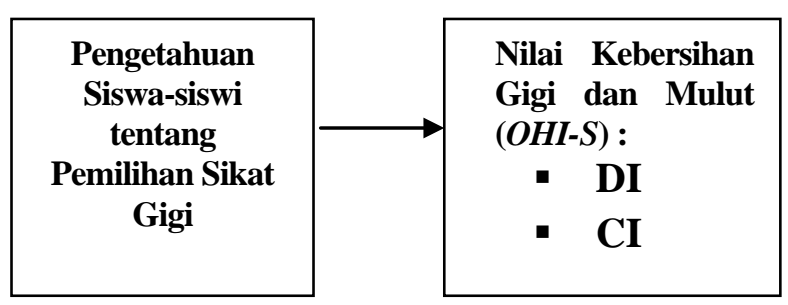

\section{Independen V. Dependen}

\section{Definisi Operasional}

Tingkat pengetahuansiswa-siswi tentang pemilihan sikat gigi adalah seberapa besar hasil tahu (pemahaman)siswa-siswi terhadap pemilihan sikat gigi yang tepat.

Tingkat kebersihan gigi dan mulut $(\mathrm{OHI}-\mathrm{S})$ adalah nilai kebersihan gigi dan mulut yang dilihat dari adanya debris dan calculus pada permukaan gigi yang dapat diukur dengan cara menjumlahkan debris index dan calculus index.

1. Debris Indeks

Debris Indeks adalah indeks (angka) yang menunjukkan atau menggambarkan ada tidaknya debris dalam mulut yang diperiksa pada gigi indeks.

2. Calculus Index adalah indeks (angka) yang menunjukkan atau menggambarkan ada tidaknya kalkulus dalam mulut yang diperiksa pada gigi indeks.

\section{Populasi Penelitian}

Populasi dalam penelitian ini adalah seluruh siswasiswikelas II CSMP Negeri 31 yang berjumlah 35 orang.

\section{Sampel Penelitian}

Sampel penelitian yang diambil yaitu total populasi yang berjumlah 35 orang.

\section{Hasil Penelitian}

Dari pengumpulan dan pengolahan data yang dilakukan, diperoleh hasil sebagai berikut :
Tabel 1. Disribusi Frekuensi Tingkat Pengetahuan Tentang Pemilihan Sikat Gigi pada Siswasiswi Kelas II C SMP Negeri 31 Jl. Jamin Ginting Km 13,5 Medan Tahun 2018

\begin{tabular}{|c|l|l|}
\hline Kriteria & Jumlah siswa-siswi & Persentase (\%) \\
\hline aik & 35 & 100 \\
\hline \hline Sedang & 0 & 6 \\
\hline Buruk & 0 & 0 \\
\hline Jumlah & 35 & 100 \\
\hline
\end{tabular}

Dari tabel 1 dapat dilihat bahwa persentase tingkat pengetahuan siswa-siswi tentang pemilihan sikat gigi dengan kriteria baik sebanyak 35 orang (100\%), dan tidak ada siswa-siswi dengan kriteria sedang dan buruk.

Tabel 2. Distribusi Frekuensi Debris Index Rata-Rata pada Siswa-siswiKelas II C SMP Negeri $31 \mathrm{Jl}$. Jamin Ginting KM 13,5 Medan Tahun 2018

\begin{tabular}{|l|l|l|l|}
\hline $\begin{array}{l}\text { Jumlah } \\
\text { Siswa-siswi }\end{array}$ & $\begin{array}{l}\text { Jumlah } \\
\text { Keselurahan } \\
\text { Debris Index }\end{array}$ & $\begin{array}{l}\text { Debris Index } \\
\text { Rata-Rata }\end{array}$ & Kriteria \\
\hline 35 & 47,88 & 1,37 & sedang \\
\hline
\end{tabular}

Dari tabel 2 diperoleh hasil bahwa seluruh siswasiswi memiliki debris index rata-rata 1,37 dengan kriteria sedang.

Tabel 3. Distribusi Frekuensi Calculus Index Rata-Rata pada Siswa-siswiKelas II C SMP Negeri 31 Jl. Jamin Ginting KM 13,5 Medan Tahun 2018

\begin{tabular}{|l|l|l|l|}
\hline Jumlah & $\begin{array}{l}\text { Jumlah } \\
\text { Siswa-siswi }\end{array}$ & $\begin{array}{l}\text { Calculus } \\
\text { Keseluruhan } \\
\text { Index Rata- } \\
\text { Index }\end{array}$ & $\begin{array}{l}\text { Kata } \\
\text { Rateria }\end{array}$ \\
\hline 35 & 25,53 & 0,72 & sedang \\
\hline
\end{tabular}

Dari tabel 3 diperoleh hasil bahwa seluruh siswasiswi memiliki calculus index rata-rata 0,72 dengan kriteria sedang.

Tabel 4. Distribusi Frekuensi OHI-S Rata-Rata pada pada Siswa-siswi Kelas II C SMP Negeri 31 Jl. Jamin Ginting KM 13,5 Medan Tahun 2018

\begin{tabular}{|l|l|l|l|}
\hline $\begin{array}{c}\text { Jumlah } \\
\text { Siswa-siswi }\end{array}$ & $\begin{array}{l}\text { Jumlah } \\
\text { Keseluruhan }\end{array}$ & $\begin{array}{l}\text { OHI-S } \\
\text { Rata-Rata }\end{array}$ & Kriteria \\
\hline 35 & 81,07 & 2,32 & sedang \\
\hline
\end{tabular}

Dari tabel 4 dapat diketahui bahwa seluruh siswasiswi memiliki OHI-S rata-rata 2,32 dengan krteria sedang.

Pembahasan

1. Tingkat Pengetahuan Tentang Pemilihan Sikat Gigi pada Siswa-siswi Kelas II C SMP Negeri 31 Jl. Jamin Ginting KM 13,5 Medan Tahun 2018

Dari tabel 1 dapat dilihat bahwasiswa-siswi yang memiliki pengetahuan dengan kriteria baik ada 35 orang (100\%) dan tidak ada yang memiliki kriteria sedang dan 
buruk. Berdasarkan data yang diperoleh dari jawaban kuesioner 35 siswa-siswi (100\%) yang telah mengetahui tentang pemilihan sikat gigi, 3 orang $(8,57 \%)$ mengetahui bahwa sikat gigi yang baik adalah sikat gigi yang memiliki kepala sikat yang kecil, karena dapat menjangkau dan membersihkan seluruh permukaan gigi.

Menurut Sondang Pintauli (2008), syarat-syarat sikat gigi yang baik adalah ukuran sikat harus mampu menelusuri bagian-bagian dalam mulut sampai gigi bagian belakang, kemudianbulu sikat hendaknya jangan terlalu keras/lembek/jarang, bulu sikat gigi yang kasar bisa menyebabkan kerusakan gusi yang berbatasan langsung dengan gigi atau yang lazim disebut dengan leher gigi, bentuk kepala sikat gigi berbentuk oval karena dapat melindungi gusi dari kemungkinan terluka, batas pemakaian sikat gigi 3 bulan.

\section{Debris Index Rata-Rata pada Siswa-siswi Kelas II C SMP Negeri 31 Jl. Jamin Ginting KM 13,5 Medan Tahun 2018}

Dari tabel 2 diperoleh diperoleh hasil bahwa seluruh siswa-siswi memiliki Debris Indexrata-rata 1,37 dengan kriteria sedang.Sandira (2009) berpendapat, untuk menentukan kebersihan gigi dan mulut seseorang dapat diukur dengan menggunakan indeks. Indeks adalah suatu angka yang menunjukan keadaan klinis gigi yang didapat pada waktu melakukan pemeriksaan, dengan cara mengukur luas permukaan gigi yang tertutup oleh debris dan kalkulus.

Debris adalah sisa makanan yang terdapat dalam rongga mulut. Angka debris indeks dapat dipengaruhi oleh jenis makanan yang dikonsumsi seseorang. Jenis makanan dapat berupa makanan berserat, berair ataupun makanan manis, lunak, dan melekat. Angka debris indeks ini dapat diturunkan dengan cara berkumur-kumur dan menyikat gigi secara teratur.

\section{Calculus Index Rata-Rata pada Siswa-siswi Kelas II C SMP Negeri 31 Jl. Jamin Ginting KM 13,5 Medan Tahun 2018.}

Dari tabel 3 diperoleh hasil bahwa bahwa seluruh siswa-siswi memiliki calculus index rata-rata 0,72 dengan kriteria sedang. Menurut Moehammad S (2008), kalkulus adalah endapan keras yang terletak pada permukaan gigi yang berwarna mulai dari kekuningkuningan, kecoklat-coklatan sampai kehitam-hitaman sehingga dapat diamati oleh mata. Salah satu tindakan yang dapat dilakukan untuk menghilangkan karang gigi adalah dengan melakukan skaling atau pembersihan karang gigi.

Menurut Sandira (2009), terbentuknya karang gigi berasal dari plak yang tinggal terlalu lama dan akan mengeras menjadi karang gigi. Adapun penyebabnya berasal dari pengendapan bahan-bahan kasar, air ludah, serum darah akibat suatu endapan.

\section{OHI-S Rata-Rata pada pada Siswa-siswi Kelas II C SMP Negeri 31 Jl. Jamin Ginting KM 13,5 Medan Tahun 2018}

Dari tabel 4 diperoleh OHI-S rata-rata pada siswa-siswi adalah dengan kriteria sedang (2,32). Menurut Pintauli, Hamada (2008), kebersihan gigi dan mulut diperiksa dengan menggunakan OHI-S.

$O H I-S$ adalah skor atau nilai pemeriksaan gigi dan mulut (Green dan Vermillion) dengan menjumlahkan Debris Index (DI) dan Calculus Index (CI). Pemeriksaan Debris Index (DI) dan Calculus Index dilakukan pada 6 gigi index.

\section{Kesimpulan}

Hasil penelitian tentang gambaran pengetahuan siswa-siswi kelas II C tentang pemilihan sikat gigi terhadap nilai kebersihan gigi dan mulut di SMP Negeri 31 Medan Tahun 2018, adalah sebagai berikut:

1. Tingkat pengetahuan siswa-siswi tentang pemilihan sikat gigi

- Baik berjumlah 35 orang (100\%)

1. Debris index rata-rata

- seluruh siswa-siswi memiliki debris index ratarata 1,37 .

2. Calculus index rata-rata

- seluruh siswa-siswi memiliki calculus index ratarata 0,72 .

3. OHI-S rata-rata.

- seluruh siswa-siswi memiliki OHI-S rata-rata 2,32 .

\section{DAFTAR PUSTAKA}

Arikunto, S, (2006), Prosedur Masalah Penelitian Suatu Pendekatan Praktik.Jakarta. Rineka Cipta.

Ginandjar, R, (2009), Pencegahan Penyakit Gigi dan Mulut, Bandung

http://wikipedia.com/Kesehatan/Medis-kesehatan-gigi

(Diakses 12 Maret 2018)

Kusumawardani, E, (2011), Cara Menjaga Kesehatan Gigi dan Mulut, Jakarta

Machfoedz, I, (2008), Menjaga Kesehatan Gigi \& Mulut, Fitramaya, Yogyakarta.

Notoatmodjo, Soekidjo, 2007, Promosi Kesehatan dan Ilmu Perilaku, Rineka Cipta. Jakarta. , 2010, Metode Penelitian Kesehatan, Rineka Cipta. Jakarta.

Nuraskin, C.A, dan Adriana H, Nelly K. M, (2012), Bahan Ajar Karya Tulis Ilmiah. Medan. USU press.

Pintauli, S, Taizo, H, (2008), Menuju Gigi Dan Mulut Sehat. Medan. USU press.

Pratiwi D, 2007, GigiSehat Merawat Gigi Sehari-hari. Jakarta, Kompas.

Rahamadhan, A.G, (2010), Serba-serbiKesehatan Gigi Dan Mulut.Bukune, Jakarta Selatan.

Saryono, (2011), Metode Penelitian Kesehatan, Mitra Cendikia Press, Jogjakarta

Susanto A, (2007), Kesehatan Gigi dan Mulut, Sunda Kelapa Pustaka, Jakarta. 